\title{
HARDINESS AND PERSONAL RESOURCES OF RED ZONE STAFF: PSYCHOLOGICAL ANALYSIS
}

Yasko BA ${ }^{1,2} \otimes$, Kazarin BV ${ }^{1}$, Gorodin VN1 ${ }^{1}$, Chugunova NA ${ }^{3}$, Pokul LV ${ }^{3,4}$, Skripnichenko LS ${ }^{2}$, Skorobogatov $W^{2}$

1 Kuban State Medical University, Krasnodar, Russia

${ }^{2}$ Kuban State University, Krasnodar, Russia

${ }^{3}$ Novorossiysk Clinical Center of FMBA, Novorossiysk, Russia

${ }^{4}$ Peoples' Friendship University of Russia, Moscow, Russia

In light of the ongoing COVID-19 pandemic, it is becoming increasingly important to address the problem of resourcefulness in the healthcare personnel of COVID-19 red zones. The aim of this study was to assess hardiness and the state of vital resources in physicians continuously working in red zones and to test a hypothesis that that long-term work in a COVID-19 red zone adversely affects the resourcefulness, reducing resistance to stress. Group $1(n=94)$ consisted of physicians with a history of employment in a COVID-19 red zone between May 2020 and June 2021; group $2(n=77)$ comprised physicians who were not involved in managing COVID-19 patients. The tests showed that hardiness and its components (commitment, control and challenge) were at high levels in group 2 (59.7\%; 67.5\%; $61.0 \% ; 20.9 \%$, respectively). The index of resourcefulness (RI; 1.24 ) reflected the prevalence of personal gains over losses in group 1 over the past year. In this group, there were no sex differences in the results. By contrast, hardiness was significantly reduced in $31.9 \%$ of the respondents in group 1 (red zone). Working in the red zone had a devastating effect on all hardiness components: the ratio of the percentages of high to low values was 8.5/27.7 for commitment, 9/6/34.0 for control and 10.6/35.1 for challenge. RI was reduced (0.77). The most pronounced loss of resources was observed in female physicians. The study found a significant mutual impact between challenge and the state of personality resources in red zone staff, which may indicate activation of proactive coping strategies and the acceptance of new professional experience.

Keywords: COVID-19, pandemic, pandemic consciousness, mental health, hardiness, personal resources

Acknowledgement: the authors thank Zotov SV, the Chief Medical Officer of the Specialized Clinical Hospital for Infectious Diseases for his assistance in organizing the study and Ostroushko MG, the Head of the HR Department of the Regional Clinical Hospital № 2, for her assistance in organizing psychological assessment.

Author contribution: Yasko BA proposed the idea and concept of the, systematized empirical data, discussed the results, and wrote the manuscript; Kazarin BV proposed the concept of the empirical study, provided tools to accumulate survey data; Gorodin VN recruited study participants, organized psychological assessment, propsoed the theoretical and methodological basis of the study; Chugunova NA carried out data acquisition and analyzed the obtained data; Pokul LV participated in the discussion of the study design and wrote the draft version of the manuscript; Skripnichenko LS provided rationale for the study and participated in the discussion about delivering psychological counselling to red zone staff; Skorobogatov W conducted statistical analysis.

Compliance with ethical standards: the study was approved by the Ethics Committee of Kuban State Medical University (Protocol № 12 dated June 29,2021 and Protocol № 14 dated June 25, 2021); informed consent was obtained from all study participants.

$\square$ Correspondence should be addressed: Bella A. Yasko

Stavropolskaya, 149, 350040, Krasnodar; shabela@yandex.ru

Received: 12.08.2021 Accepted: 26.08.2021 Published online: 30.08.2021

DOI: $10.24075 /$ brsmu.2021.042

\section{ЖИЗНЕСТОЙКОСТЬ И ПЕРСОНАЛЬНЫЕ РЕСУРСЫ ВРАЧЕЙ «КРАСНЫХ ЗОН» КОВИД-ГОСПИТАЛЕЙ: ПСИХОЛОГИЧЕСКИЙ АНАЛИЗ}

Б. А. Ясько ${ }^{1,2}$, Б. В. Казарин ${ }^{1}$ В. Н. Городин ${ }^{1}$ Н. А. Чугунова ${ }^{3}$, Л. В. Покуль ${ }^{3,4}$, Л. С. Скрипниченко², В. В. Скоробогатов²

${ }^{1}$ Кубанский государственный медицинский университет, Краснодар, Россия

${ }^{2}$ Кубанский государственный университет, Краснодар, Россия

${ }^{3}$ Новороссийский клинический центр Федерального медико-биологического агентства, Новороссийск, Россия

${ }^{4}$ Российский университет дружбы народов, Москва, Россия

В связи с продолжающейся пандемией COVID-19 особенно актуален вопрос о состоянии психологических ресурсов у врачей, продолжительно работающих в условиях «красных зон». Целью работы было проанализировать специфику состояния жизнестойкости и персональных (витальных) ресурсов врачей, продолжительно работающих в «красной зоне», и проверить гипотезу о том, что продолжительная профессиональная деятельность врачей в «красной зоне» оказывает негативное влияние на систему экзистенциальных и витальных ресурсов, сокращая потенциал стрессоустйчивости личности. Группу 1 ( $n$ = 94) составили врачи, вовлеченные с мая 2020 г. по июнь 2021 г. в «красную зону» ковид-госпиталей; группу 2 ( $n=77)$ - врачи, не участвовавшие в клиническом процессе с ковидными пациентами. По результатам диагостики, врачи группы 2 характеризуются высоким уровнем жизнестойкости и ее компонентов «Вовлеченность», «Контроль», «Принятие риска» (59,7\%; 67,5\%; 61,0\%; 20,9\% соответственно). В индексе ресурсности (ИР) (1,24) отражено преобладание персональных приобретений над потерями за прошедший год. Отсутствуют различия по полу. У 31,9\% врачей «красных зон» (группа 1) значительно сократился потенциал жизнестойкости. Разрушительному воздействию подверглись все компоненты жизнестойкости: соотношение \%-долей высоких/низких значений следующее: «Вовлеченность» - 8,5/27,7; «Контроль» - 9,6/34,0; «Принятие риска» — 10,6/35,1. ИР снижен (0,77). Наиболее выражено сокращение ресурсов у врачей женского пола. Установлено значимое взаимовлияние принятия риска и динамики персональных ресурсов у врачей «красной зоны», что может указывать на активизацию проактивного совладания с опорой на принятие нового профессионального опыта.

Ключевые слова: пандемия, COVID-19, пандемическое сознание, психологическое здоровье, жизнестойкость, персональные ресурсы

Благодарности: главному врачу Специализированной клинической инфекционной больницы МЗ Краснодарского края С. В. Зотову - за организационную поддержку процесса исследования начальнику отдела кадров Краевой клинической больницы № 2 МЗ Краснодарского края М. Г. Остроушко - за организацию процедур психодиагностики групп врачей.

Вклад авторов: Б. А. Ясько - идея и концепция публикации, систематизация эмпирических данных, обсуждение результатов; подготовка статьи; Б. В. Казарин - концепция эмпирического исследования, предоставление базы кафедры для аккумуляции массива данных психодиагностики; В. Н. Городин - подбор испытуемых, организация психодиагностических обследований, обсуждение теоретико-методологических основ исследования; Н. А. Чугунова - предоставление эмпирической базы, сбор материала, анализ данных; Л. В. Покуль - обсуждение дизайна исследования, подготовка черновика статьи; Л. С. Скрипниченко - обоснование актуальности исследования; обсуждение маршрутов психологической поддержки врачей «красных зон»; В. В. Скоробогатов - статистическая обработка данных.

Соблюдение этических стандартов: исследование одобрено этическим комитетом КубГМУ (протокол № 12 от 29 июня 2021 г. и протокол № 14 от 25 июня 2021 г.); все респонденты подписали добровольное информированное согласие на участие в исследовании.

$\bowtie$ Для корреспонденции: Бэла Аслановна Ясько ул. Ставропольская, д. 149, 350040, г. Краснодар; shabela@yandex.ru

Статья получена: 12.08.2021 Статья принята к печати: 26.08.2021 Опубликована онлайн: 30.08.2021

DOI: $10.24075 /$ vrgmu.2021.042 
The coronavirus has been rampant for over a year now. In all corners of the world, healthcare workers have been on the frontline of the battle against COVID-19. The losses suffered in the strenuous battle for patients' lives and the gains from this experience require detailed analysis.

The first steps in studying the impact of the COVID-19 pandemic on different demographic groups have been already made. The emotional response to the COVID threat in the early months of the pandemic was recognized by psychiatrists and psychologists as a mental health crisis. Prompt measures were expected of public health agencies to deliver psychological support to those in need $[1,2]$. Today, questionnaire survey data collected during the first phase of the pandemic are being actively studied by psychology researchers. Their main focus is on coping strategies, risk factors of posttraumatic stress, and changes in the individual and collective consciousness provoked by the ongoing pandemic. An online survey conducted after the 2020 spring to summer lockdown revealed how proactive coping was implemented in different age groups [3]. Drawing on the concept of proactive coping [4], a group of researchers established that the most resourceful coping strategy for young people in the pandemic circumstances, given the low level of stress, was a search for information. At older age, proactive strategies were more diverse, regardless of the amount of stress, suggesting that older adults had a more stable coping system. Another research team analyzed psychological factors contributing to COVID-19-associated posttraumatic stress among Chinese students living in China and abroad. The analysis revealed that students who preferred proactive coping strategies had less pronounced symptoms of COVID-19-related posttraumatic stress disorder than those who resorted to passive coping [5].

The sociopsychological context of the pandemic was analyzed in a series of surveys conducted by the leading Russian psychologists [6]. A divide in society and in the expert community was exposed: there were confronting groups of COVID dissidents and COVID rigorists, which indeed disrupted the positive effect of containment measures. These findings are consistent with the conclusion about the lack of commitment to vaccination among different population groups. This creates barriers to effective communication between the doctor and the patient [7].

A review of the literature on the psychological impact of the pandemic reveals a paucity of data on the resourcefulness of healthcare personnel working in COVID hospitals. Here, the methodology of the resource-based approach that relies on the tenets of existential psychology and psychotherapy elaborated by Frankl, Maddi and Hobfoll [8-15] can serve as a theoretical and methodological basis for empirical research. Hardiness is the most important concept in the context of resourcefulness; it is defined as an attitude that helps a person to stay engaged and avoid the devastating effects of stress $[9,16]$. According to Maddi, hardiness provides the courage to not deny stress and to turn stress into an opportunity [16]. A few recent studies demonstrated that high hardiness was a resource for patients with cardiovascular disorders [17], insomnia [18] and depression [19]. Within the scope of our interest are publications that unlock the potential of hardiness in resisting occupational stress in a clinical setting. For example, a study reports a negative correlation between low hardiness and high burnout levels in healthcare workers [20]. Another study demonstrates a link between hardiness and the attitude to work among healthcare professionals [21]. As an integral personality trait, hardiness is determined by professional engagement, satisfaction from work and is not significantly associated with age [22].
Foreign publications also discuss hardiness in the context of resistance to occupational stress. For example, hardiness is a mediator between perceived stress and happiness in nurses [23]. Resilience and well-being of hospice staff, their view of themselves as socially engaged and mentally healthy individuals are significantly correlated with high levels of hardiness [24]. A study conducted on a large sample size in China reports a strong positive correlation between hardiness and physical and mental health in hospital nurses [25].

Apart from the concept of hardiness as an existential resource that confers resistance to stressors, the concept of adaptive resources is also shared by many researchers [26-28]. According to Hobfoll, humans can draw from a variety of means to endure stress [26]. These resources can be broken down in 3 categories, one of them being significance for survival. Vital resources can be grouped into fundamental (essential for survival), secondary, which bolster fundamental resources (e.g., social support) and tertiary (social status, etc.) This approach was used to build a theoretical base for the psychological counseling of individuals facing a critical loss of resources or obstacles for their adequate repletion [28].

Based on the heuristic concepts of hardiness and adaptive resources and the concept of mental health formulated by $\mathrm{WHO}$ [29], we defined the aim of this study: to assess hardiness and the state of vital resources in red zone staff and to test the hypothesis that long-term (one year long) work in a COVID red zone adversely affects the resourcefulness of an individual, reducing their resistance to stress.

\section{METHODS}

The study was conducted on a sample of physicians from different healthcare institutions of Krasnodar and Krasnodar region during the COVID-19 pandemic (May 2020 - June 2021).

Two groups were formed. The main group (group 1) consisted of physicians who had been working in COVID-19 red zones during the specified period $(n=94)$; the control group (group 2) comprised physicians who had not been involved in managing COVID-19 patients $(n=77)$. In group 1, 60.0\% ( $n=62$ ) of the participants were women and $34.0 \%$ $(n=32)$ were men; in group 2, women made up $66.2 \%(n=51)$, whereas men, 33.8\% $(n=26)$.

The following inclusion criteria were applied: physicians with a specialty in general medicine; age under 55 years; no life crisis accompanied by emotional distress during the specified period; a history of working in a COVID-19 red zone for group 1 and no such history for group 2.

Exclusion criteria: age above 55 years; a serious life crisis between May 2020 and June 2021.

The methodological principles of subjective activity and resourcefulness concepts $[9,10,26,27,30]$ were used as a theoretical and methodological basis of our empirical research. Psychological assessment was conducted using surveys based on the theoretical constructs of hardiness [9, 10] and human resource psychology [26-28], including the Hardiness test [31] and the Loss and Gain of Resources test [32].

The Hardiness test is a tool for assessing 3 components that, according to the existential concept, make up hardiness: commitment, control and challenge. Commitment is defined as a conviction that involvement in life results in the highest chance to find something worthy and meaningful [31]. The lack of such conviction breeds a feeling of rejection, a sense of being an outcast in life. The control component shows how confident a person is in his/her ability to change the course of events. A low control score indicates helplessness in a given circumstance. 
Table 1. Descriptive statistics for hardiness in the studies groups of red zone physicians

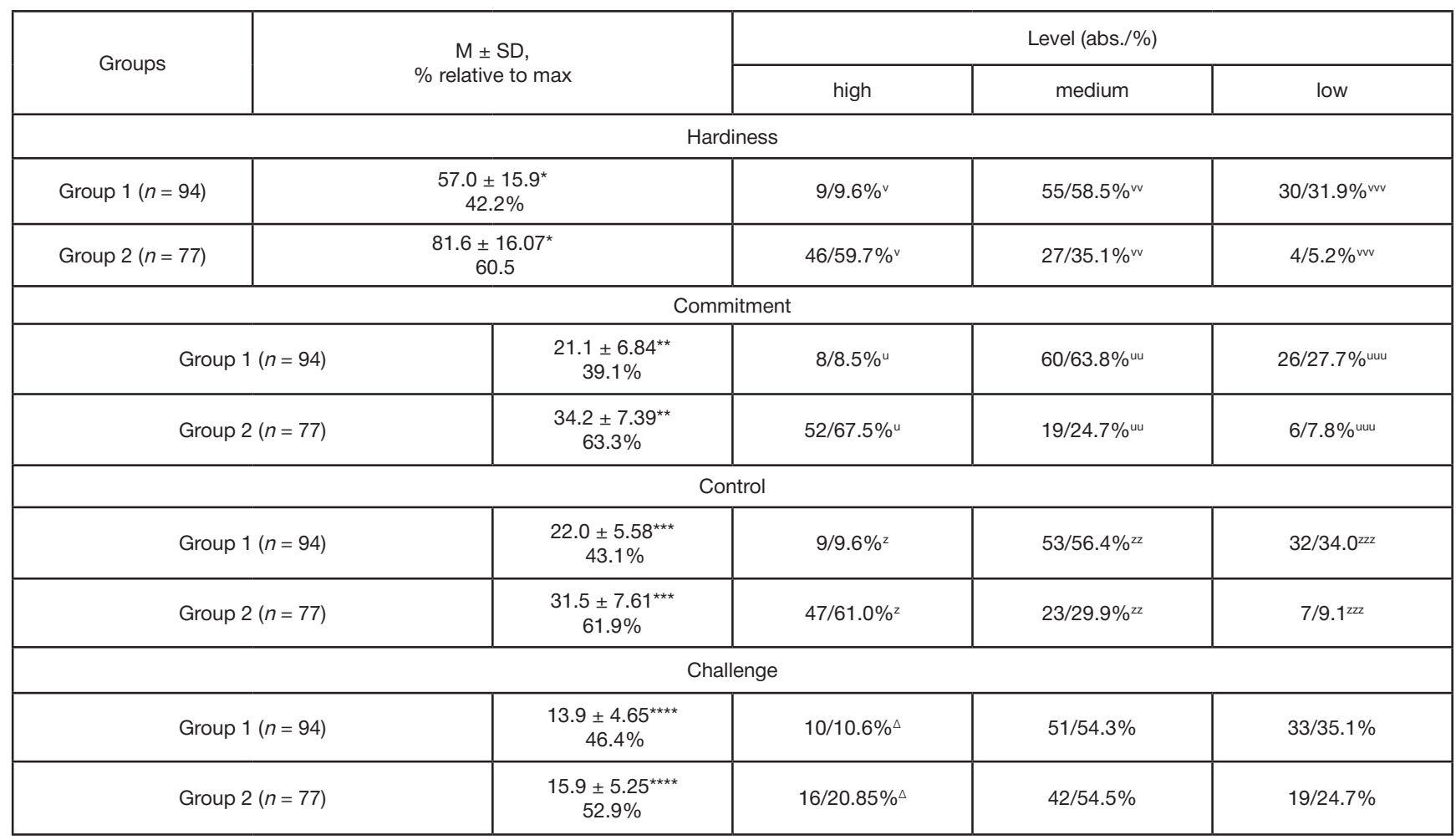

Note: Student's $t$ test: ${ }^{*}-t=9.99 ; p<0.001 ;{ }^{* \star}-t=11.9 ; p<0.001 ;{ }^{* \star}-t=9.13 ; p<0.001 ;{ }^{* \star \star}-t=2.57 ; p<0.05$. Fisher's criterion: ${ }^{\vee}-\varphi^{*}=7.39$; $p \leq 0.001 ; w-\varphi^{*}=3.09 ; p \leq 0.001 ; w v-\varphi^{*}=4.81 ; p \leq 0.001 ;{ }^{u}-\varphi^{*}=15.9 ; p \leq 0.001 ;$ u $-\varphi^{*}=9.65 ; p \leq 0.001 ;$ uu $-\varphi^{*}=6.47 ; p \leq 0.001 ; z-\varphi^{\star}=7.56$; $p \leq 0.001 ; z z-\varphi^{*}=3.53 ; p \leq 0.001 ; z z z-\varphi^{*}=4.14 ; p \leq 0.001 ;{ }^{\Delta}-\varphi^{*}=1.84 ; p \leq 0.033$.

Challenge exposes a conviction that whatever happens to a person, it promotes personal growth through knowledge gained from experience and the practical application of this knowledge [31]. The Hardiness test allows assessing the ability and willingness to be active and flexible in a difficult life situation and vulnerability to stress.

The respondents were offered to fill out a questionnaire that contained 45 statements describing different aspects of hardiness. The respondents reported their attitude to each statement by choosing one of four available options (no, more likely no than yes, more likely yes than no, yes). Each answer was rated on the scale from 0 to 3 . Since the number of statements describing each hardiness component was different (18 statements for commitment, 17 statements for control and 10 statements for challenge), we compared the total score to the maximum possible total score and expressed the obtained value in \%.

The "Loss and Gain of Resources" test [32] was used to analyze the interplay between vital resources during a certain time period (which in our case was from May 2020 to June 2021). The tests consisted of 2 identical lists of 30 resources (intrapersonal, social, material). The respondents rated their emotional response to the gain or loss of a resource on the list on a 5-point scale. The index of resourcefulness (RI) was calculated for each participant as a ratio of the total gain score to the total loss score. The authors of the test propose 3 levels of resourcefulness: low $(\mathrm{Rl}<0.8)$, medium $(\mathrm{RI}$ from 0.8 to 1.2$)$ and high $(\mathrm{RI}>1.2)[32]$.

Statistical analysis was carried out in SPSS 26.0 (An IBM Company; USA). Both parametric and nonparametric statistical methods were applied (means, standard deviations, Student's $t$ test, Pearson's correlation coefficient $r$, and Fisher's $\left.\varphi^{\star}\right)$. The decision to use parametric statistics was based on the results of Levene's $F$ test for the homogeneity of variance. The results of the $\mathrm{F}$ test for the entire sample and its subsamples corresponded to the significance level $<95.0 \%(p>0.05)$, confirming the homogeneity of variance and justifying the use of parametric statistics.

\section{RESULTS}

\section{Hardiness in Covid red zone staff (Group 1)}

Of 94 respondents, high hardiness was observed in only 9 persons (9.6\%). More than half of the respondents working in the red zone showed a medium level of hardiness $(58.5 \% ; n=55)$; one-third of the red zone physicians $(31.9 \% ; n=30)$ had low ability to tolerate stress and maintain inner balance (Table 1).

The average hardiness score in group 1 was 57 points $(\mathrm{SD}=15.9)$, i.e. at the borderline between medium and low values (42.2\%). The commitment score was the lowest (39.1\% relative to the maximum on this scale). Only $8.5 \%$ of the respondents $(n=8)$ showed high levels of commitment. Eighty-six respondents had low $(27,7 \% ; n=26)$ or medium $(67.8 \%$; $n=60$ ) levels of commitment. Control and challenge scores in this group were in the lower part of the medium values spectrum: $43.1 \%$ and $46.4 \%$, respectively, relative to the maximum possible scores on these scales. Eighty-five respondents from group 1 scored low (34.0\%; $n=32$ ) or medium (56.4\%; $n=53$ ) on the control scale. Only $9.6 \%$ of the physicians $(n=9)$ demonstrated high levels of subjective control over the course of events in the presence of occupational stress. High challenge scores were observed in 10 respondents (10.6\%). Other 84 doctors in this group had low $(35,1 \% ; n=33)$ or medium (54.3\%; $n=51)$ challenge scores reflecting their level of willingness to grow from experience by taking risks.

There is a sex difference in hardiness among red zone physicians (Table 2). 
Table 2. Descriptive statistics for hardiness among male and female participants in group 1

\begin{tabular}{|c|c|c|c|c|c|c|}
\hline \multicolumn{7}{|c|}{ Hardiness } \\
\hline $\mathrm{M} \pm \mathrm{SD}$ & \multicolumn{3}{|c|}{ Men: $71.8 \pm 12.10^{*}$} & \multicolumn{3}{|c|}{ Women: $54.4 \pm 15.5^{\star}$} \\
\hline \multicolumn{7}{|c|}{ Levels } \\
\hline & \multicolumn{2}{|c|}{ high (total; \%) } & \multicolumn{2}{|c|}{ medium (total; \%) } & \multicolumn{2}{|c|}{ low (total; \%) } \\
\hline Men & 4 & 6.5 & 35 & 56.5 & 23 & $37.1^{\mathrm{v}}$ \\
\hline Women & 5 & 15.6 & 20 & 62.5 & 7 & $21.9^{v}$ \\
\hline \multicolumn{7}{|c|}{ Commitment } \\
\hline$M \pm S D$ & \multicolumn{3}{|c|}{ Men: $23.8 \pm 5.78^{\star *}$} & \multicolumn{3}{|c|}{ Women: $19.7 \pm 6.90^{\star \star}$} \\
\hline \multicolumn{7}{|c|}{ Levels } \\
\hline & \multicolumn{2}{|c|}{ high (total; \%) } & \multicolumn{2}{|c|}{ medium (total; \%) } & \multicolumn{2}{|c|}{ low (total; \%) } \\
\hline Men & 5 & 15.6 & 22 & 68.8 & 5 & $15.6^{\mathrm{vv}}$ \\
\hline Women & 3 & 4.8 & 38 & 61.3 & 21 & $33.9^{\mathrm{vv}}$ \\
\hline \multicolumn{7}{|c|}{ Control } \\
\hline $\mathrm{M} \pm \mathrm{SD}$ & \multicolumn{3}{|c|}{ Men: $23.5 \pm 5.8$} & \multicolumn{3}{|c|}{ Women: $21.2 \pm 5.3$} \\
\hline \multicolumn{7}{|c|}{ Levels } \\
\hline & \multicolumn{2}{|c|}{ high (total; \%) } & \multicolumn{2}{|c|}{ medium (total; \%) } & \multicolumn{2}{|c|}{ low (total; \%) } \\
\hline Men & 4 & 12.5 & 21 & 65.6 & 7 & $21.9^{\text {ww }}$ \\
\hline Women & 5 & 8.1 & 32 & 51.6 & 25 & $40.3^{\text {wv }}$ \\
\hline \multicolumn{7}{|c|}{ Challenge } \\
\hline $\mathrm{M} \pm \mathrm{SD}$ & \multicolumn{3}{|c|}{ Men: $14.7 \pm 5.20$} & \multicolumn{3}{|c|}{ Women: $13.5 \pm 4.33$} \\
\hline \multicolumn{7}{|c|}{ Levels } \\
\hline & \multicolumn{2}{|c|}{ high (total; \%) } & \multicolumn{2}{|c|}{ medium (total; \%) } & \multicolumn{2}{|c|}{ low (total; \%) } \\
\hline Men & 5 & 15.6 & 16 & 50 & 11 & 34.4 \\
\hline Women & 5 & 8.1 & 35 & 56.4 & 22 & 35.5 \\
\hline
\end{tabular}

Note: Student's $t$ test: ${ }^{*}-t=5.99 ; p<0.001 ;{ }^{* \star}-t=3.1 ; p<0.01$. Fisher's criterion: ${ }^{v}-\varphi^{\star}=1.54 ; p \leq 0.06 ;{ }^{w}-\varphi^{\star}=2.0 ; p \leq 0.02 ;{ }^{w}-\varphi^{\star}=1.85 ; p \leq 0.03$.

Medium hardiness scores $(\mathrm{M} \pm \mathrm{SD}$ ) were prevalent in the male subsample $(t=5.99 ; p<0.001$ ), whereas the female subsample was dominated by low hardiness scores $\left(\varphi^{*}=1.54\right.$; $p \leq 0.06)$. The level of commitment also differed between the sexes $(t=3.1 ; p<0.01)$. The female subsample was dominated by low commitment $\left(\varphi^{*}=2.0 ; p \leq 0.03\right)$ and low control $\left(\varphi^{\star}=1.85 ; p \leq 0.02\right)$ scores.

\section{Hardiness in physicians not involved in management of COVID-19 patients (group 2)}

In group 2, the average hardiness score was 81.6 points $(\mathrm{SD}=16.07)$, i.e. high $(60.5 \%$ relative to the maximum hardiness score; see Table 1).

On the whole, these findings were consistent with the results of another study conducted in physicians [33]. In that study, physicians with over 5 years of professional experience scored an average of 70.4 points on hardiness, and their commitment, control and challenge scores were 33.2, 24.1 and 13.08 , respectively.

In our study, there was a significant difference in the level of hardiness between the groups $(t=9.99 ; p<0.001)$. Of 77 respondents in group 2, 59.7\% $(n=46)$ demonstrated a higher level of hardiness than those in group $1\left(\varphi^{*}=7.39 ; p \leq 0.001\right)$. Reduced tolerance to stress, compromising inner balance and preventing the person from succeeding in their activities, was observed in only $5.2 \%$ of the respondents in group $2(n=4)$; the difference in this parameter was significant between the groups $\left(\varphi^{\star}=4.81 ; p \leq 0.001\right)$. Medium hardiness was observed in $35.1 \%$ of the respondents $(n=27)$ in group 2 , which was much lower than in group $1\left(\varphi^{\star}=3.09 ; p \leq 0.001\right)$. In group 2, high tolerance to stress was detected in $59.7 \%$ of the respondents $(n=46)$, which was a significantly higher value than in group 1 $\left(\varphi^{\star}=7.39 ; p \leq 0.001\right)$.

Unlike red zone doctors, doctors from group 2 demonstrated significantly higher levels of commitment and control (see Table 1). More than half of the respondents in group $2(67.5 \% ; n=52)$ reported being actively involved in their daily activities. Low commitment was detected in only $7.8 \%$ $(n=6)$ of the respondents in group 2. In comparison with group 1 , individuals with high commitment prevailed in group 2; group 1 was dominated by individuals with low commitment $\left(\varphi^{\star}=15.9\right.$ and $\varphi^{\star}=6.47$, respectively; $p \leq 0.001$ ).

The average control score (the ability to change the course of events) in group 2 was quite high ( $\mathrm{M}=31.5 \pm 7.61 ; 61.9 \%$ from the maximum on this subscale) and significantly higher than in group $1(t=9.13 ; p<0.001)$. Only 7 respondents in group $2(9.1 \%)$ scored low on the control scale, and $61.0 \%$ $(n=47)$ thought they were able to control events in their life and make a difference. High control scores were prevalent in group $2\left(\varphi^{*}=7.56 ; p \leq 0.001\right)$, as compared to group 1 , dominated by low and medium control scores $\left(\varphi^{\star}=3.53\right.$ and $\varphi^{\star}=4.14$, respectively; $p \leq 0.001$ ).

The average challenge score, i.e. a conviction that every event in life can promote personal growth, was 15.9 points in group 2 ( $S D=5.25)$, which was significantly higher than in group 1 ( $t=2.57$; $p<0.05)$, although both parameters fell within the range of medium values. High willingness to take risks was observed in $20.8 \%$ of the participants in group $2(n=16)$, which again was significantly higher than in group $1\left(\varphi^{\star}=1.84 ; p \leq 0.033\right)$. However, there were no significant differences in medium and low challenge scores between the groups. 
Table 3. Descriptive statistics for hardiness among male and female participants in group 2

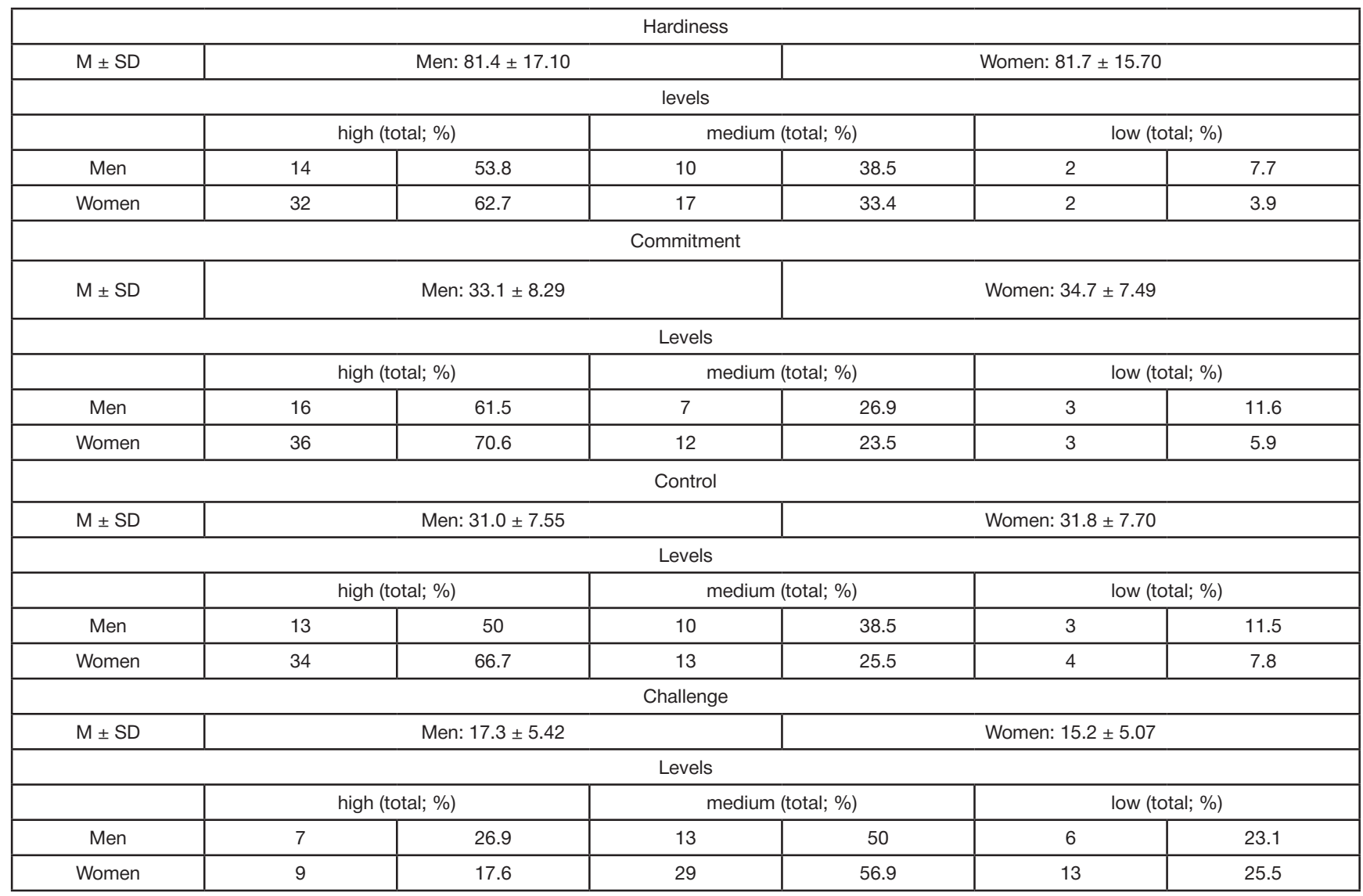

Interestingly, there were no sex difference in the analyzed parameters among the male and female respondents in group 2 (Table 3).

\section{Gain and loss of resources in red zone staff (group 1)}

The average $\mathrm{Rl}$ in group 1 was low $(0.77)$, indicating the prevalence of personal losses over gains in the past year (Table 4). The RI was low for 53 respondents (56.4\%) and medium in 32 (34.0\%) respondents. Only 9 doctors (9.6\%) scored slightly higher on total gains than on total losses; this was largely due to the maximum possible rates $(4 ; 5)$ given to the following statements: I feel needed; My achievements are recognized by close others; I get support from colleagues.

Low Rl was prevalent in the female subgroup vs. the male subgroup (61.3\% and 37.5\%, respectively; $\varphi^{\star}=2.21 ; p \leq 0.013$ ).
Gain and loss of resources in physicians not involved in management of COVID-19 patients (group 2)

The average $\mathrm{RI}$ in group 2 was high (1.24), indicating the prevalence of personal gains over losses in the past year. The RI was low for $26.0 \%$ of the respondents $(n=20)$. More than half of the doctors in group 2 thought that they had increased their resourcefulness in the past year $(57.1 \% ; n=44)$. All studied parameters differed significantly between the groups (Table 4).

\section{Correlation analysis}

Strong negative and positive correlations were established between hardiness, its constituents and the loss and gain scores (Table 5).

Most of the detected correlations were characterized by significant $(0.05<p<0.1)$ negative or positive values of the

Table 4. Descriptive statistics for resource gains and losses in the compared groups

\begin{tabular}{|c|c|c|c|c|c|c|}
\hline & \multicolumn{3}{|c|}{$\mathrm{M} \pm \mathrm{SD}$} & \multicolumn{3}{|c|}{ RI (abs./\%) } \\
\hline & Losses & Gains & RI & low & medium & high \\
\hline Group 1 & $107.1 \pm 15.5^{\star 1}$ & $79.9 \pm 23.1^{\star 2}$ & 0.77 & $53 / 56.4^{\wedge 1}$ & $32 / 34.0^{\wedge 2}$ & $9 / 9.6^{\wedge 3}$ \\
\hline Men & $107.3 \pm 16.2^{\star 3 \wedge}$ & $87.8 \pm 22.53$ & 0.82 & $15 / 46.91^{\circ}$ & $13 / 40.6^{\Delta 1}$ & $4 / 12.5^{\curlyvee 1}$ \\
\hline Women & $107.0 \pm 15.3^{\star 4 \wedge}$ & $75.9 \pm 22.51^{* 5}$ & 0.71 & $38 / 61.31^{\circ \mathrm{v} 1}$ & $19 / 30.6^{\Delta 2}$ & $5 / 8.1^{\mathrm{Y} 2}$ \\
\hline Group 2 & $88.4 \pm 18.60^{\star 1}$ & $102.05 \pm 23.04^{\star 2}$ & 1.24 & $20 / 26.0^{\wedge 1}$ & $13 / 16.9^{\wedge 2}$ & $44 / 57.1^{\wedge 3}$ \\
\hline Men & $90.8 \pm 18.7^{\star 3}$ & $98.9 \pm 22.7$ & 1.17 & $8 / 30.8$ & $4 / 15.4^{\Delta 1}$ & $14 / 53.8^{\mathrm{Y} 1}$ \\
\hline Women & $87.2 \pm 18.0^{\star 4}$ & $103.7 \pm 23.3^{\star 5}$ & 1.2 & $12 / 23.5^{v 1}$ & $9 / 17.6^{\Delta 2}$ & $30 / 58.8^{\mathrm{Y} 2}$ \\
\hline
\end{tabular}

Note: Student's $t$ test. losses: ${ }^{* 1}-t=7.03 ; p<0.001 ;{ }^{* 3}-t=3.56 ; p<0.01 ;{ }^{*}-t=6.22 ; p<0.001 ;$ gains: ${ }^{* 2}-t=6.24 ; p<0.001 ;{ }^{*} 5-t=6.41 ; p<0.001$. Fisher's criterion. RI levels, low: ${ }^{10}-\varphi^{\star}=2,21, p \leq 0.013 ;{ }^{\wedge 1}-\varphi^{\star}=2.41, p \leq 0.007 ;{ }^{v 1}-\varphi^{\star}=4.16, p \leq 0.001 ;$ medium: ${ }^{\wedge 2}-\varphi^{\star}=2.59, p \leq 0.004 ;{ }^{\Delta 1}-\varphi^{\star}=2.17$, $p \leq 0.015 ;{ }^{\Delta 2}-\varphi^{*}=1.61 . p \leq 0.05 ;$ high: ${ }^{\wedge} 3-\varphi^{*}=7.04, p \leq 0.001 ;{ }^{\Upsilon 1}-\varphi^{\star}=3.50, p \leq 0.001 ;{ }^{\Upsilon 2}-\varphi^{*}=6.19, p \leq 0.001$. 
Table 5. The correlation matrix (r) for hardiness, its components and gain and loss scores on the self-assessment scale

\begin{tabular}{|c|c|c|c|c|c|}
\hline \multicolumn{3}{|c|}{ Group 1} & \multicolumn{3}{|c|}{ Group 2} \\
\hline \multicolumn{3}{|c|}{ Total $(n=94)$} & \multicolumn{3}{|c|}{ Total $(n=77)$} \\
\hline & losses & gains & & losses & gains \\
\hline Commitment & -0.491 & 0.677 & Commitment & -0.661 & 0.74 \\
\hline Control & -0.508 & 0.597 & Control & -0.624 & 0.701 \\
\hline Challenge & -0.556 & 0.561 & Challenge & $-0.128^{*}$ & $0.238^{*}$ \\
\hline Hardiness & -0.551 & 0.663 & Hardiness & -0.641 & 0.75 \\
\hline \multicolumn{3}{|c|}{ Women $(n=62)$} & \multicolumn{3}{|c|}{ Women $(n=51)$} \\
\hline Commitment & -0.501 & 0.623 & Commitment & -0.608 & 0.72 \\
\hline Control & -0.484 & 0.54 & Control & -0.577 & 0.717 \\
\hline Challenge & -0.453 & 0.498 & Challenge & $-0.069^{*}$ & $0.258^{*}$ \\
\hline Hardiness & -0.516 & 0.602 & Hardiness & -0.573 & 0.752 \\
\hline \multicolumn{3}{|c|}{ Men $(n=32)$} & \multicolumn{3}{|c|}{ Men $(n=26)$} \\
\hline Commitment & -0.561 & 0.646 & Commitment & -0.74 & 0.777 \\
\hline Control & -0.583 & 0.646 & Control & -0.711 & 0.666 \\
\hline Challenge & -0.733 & 0.65 & Challenge & $-0.295^{\star}$ & $0.273^{*}$ \\
\hline Hardiness & -0.665 & 0.723 & Hardiness & -0.766 & 0.757 \\
\hline
\end{tabular}

Note: * $-r$ is below the significance threshold $(p>0.05)$.

$r$-coefficient in both samples. The established correlations were not sex-specific. Nevertheless, in group 2 the challenge score and the loss and gain score were mutually influential. Unlike group 1, in group 2 gains and losses were not associated significantly with experience acquired over the past year and the practical application of this experience. In general, in group 2 and male and female subgroups, the correlation coefficient was below the critical threshold for the corresponding sample size $(p>0.05)$

\section{DISCUSSION}

Our findings indicate a negative psychological effect of longterm work in a COVID-19 red zone. All studied parameters were significantly lower in red zone staff than in healthcare workers not involved in the management of COVID-19 patients. Work overload and daily emotional distress undermine the ability to endure occupational stress and maintain inner balance (hardiness). This is most clearly manifested in reduced commitment, the feeling of being rejected or being an outsider to life, development of a non-constructive pandemic consciousness, i.e. a growing conviction that it is impossible to have control over one's own life or influence the course of events, and helplessness in difficult life situations and in the presence of occupational stress.

Direct consequences of low hardiness include low RI, the lack of personal resources, the prevalence of losses over gains, and a pessimistic assessment of personal gains.

The analysis of data generated by group 1 shows that men are slightly more successful in preserving their commitment than women. This is also reflected in higher $\mathrm{Rl}$ among males, which falls within a domain of medium values (0.82 vs. 0.71 in women).

Group 2 was characterized by better hardiness potential and stronger vital resources. Drawing on the literature data [33], we conclude that the discovered characteristics of group 2 could be viewed as an element in the psychological profile of Russian physicians that enriches the psychological model of a medical doctor's personality [34].

The established correlations suggest a systemic link between existential and vital resources of a medical doctor. The role of challenge in the perception of resource gains and losses by red zone staff, contrary to physicians not involved in the management of COVID-19 patients, may indicate the ongoing pursuit of meaning in the professional activity. The search for meaning may reflect the activation of proactive coping strategies (transformational coping, according to Maddi) in an effort to maintain resistance to stress. These findings are consistent with the literature [35].

High levels of resource losses reported by red zone physicians may be attributed to the weakness of their existential resources, whereas high levels of hardiness and its components among other physicians are directly associated with their optimistic assessment of resource dynamics, with gains prevailing over losses.

\section{CONCLUSIONS}

Modern psychology, including occupational medical psychology, is confronted with the psychosocial consequences of the COVID-19 pandemic that require thorough and prompt analysis. Our study has confirmed the hypothesized negative impact of long-term (one year long) work in a COVID-19 red zone on the system of existential and vital resources, compromising resistance to stress. The most pronounced manifestation of this process is significant depletion of personality resources, reduced hardiness (ability to endure stress), reduced adaptive potential of being involved in and having control over one's own life. As these tendencies progress, they may result in the existential vacuum, a personality crisis characterized by the lack of meaning of one's existence. This may breed noogenic neurosis, i.e. disruption of psychological well-being, which is the critical component of human health. Our findings may be used to create a roadmap for psychological counselling of healthcare workers during the ongoing pandemic. Such counseling should focus on the activation of commitment as a component of hardiness, finding the meaning in professional activities, acknowledging the significance of professional experience, repletion of vital resource, including rest, acquiring basic knowledge of psychophysiological self-regulation and stress reduction, and formation of proactive coping strategies. 
1. Tverdohlebova TI, Kovaljov EV, Karpushhenko GV, Kulak MA Dumbadze OS, Litovko AR i dr. Social'no-jekonomicheskie aspekty COVID-19 na primere Rostovskoj oblasti. Infekcionnye bolezni. 2020; 18 (4): 27-32. DOI: 10.20953/1729-9225-2020-427-32. Russian.

2. Sorokin MYu, Kasyanov ED, Rukavishnikov GV, Makarevich OV, Neznanov NG, Lutova NB, et al. Structure of anxiety associated with COVID-19 pandemic: the online survey results. Bulletin of RSMU. 2020; 3: 70-76.

3. Kuftjak EV, Behter AA. Stress i proaktivnoe sovladajushhee povedenie $v$ period pandemii Covid-19: dannye onlajn-oprosa. Medicinskaja psihologija v Rossii. 2020; 12; 6 (65) [cited 2021 July 13]. Dostupno po ssylke: http://mprj.ru/archiv_global/2020_6_65/ nomer05.php. Russian.

4. Aspinwall LG, Taylor SE. Modeling cognitive adaptation: A longitudinal investigation of the impact of individual differences and coping on college adjustment and performance. Journal of Personality and Social Psychology. 1992; 63; 6: 989-1003. DOI: 10.1037//0022-3514.63.6.989.

5. Czyhan L, Sjao Gan V. Psihologicheskie faktory posttravmaticheskogo stressa, vyzvannogo pandemiej COVID-19. Psihologicheskij zhurnal. 2021; 42; 1: 102-10. Russian.

6. Jurevich AV, Ushakov DV, Jurevich MA. COVID-19: rezul'taty tret'ego jekspertnogo oprosa. Psihologicheskij zhurnal. 2021; 42; 3: 28-136. Russian.

7. Platonova TA, Golubkova AA, Smirnova SS, D'jachenko EV. Aktual'nye voprosy organizacii immunoprofilaktiki naselenija. Kommunikativnye riski - nereshennye problemy i novye vozmozhnosti. Infekcionnye bolezni. 2020; 18 (3): 112-8. DOl: 10.20953/1729-9225-2020-3-112-118. Russian.

8. Frankl V. Chelovek v poiskah smysla. M.: Progress, 1990; 368 s. Russian.

9. Maddi S. Hardiness: an Operationalization of Existential Courage. Journal of Humanistic Psychology. 2007; 44; 3: 279-98.

10. Maddi S. Hardiness: The courage to grow from stresses. The Journal of Positive Psychology. 2006; 1 (3): 160-8.

11. Odincova MA. Psihologija zhiznestojkosti. M.: FLINTA, 2015; 296 s. Russian.

12. Jaroshhuk IV. Psihologija zhiznestojkosti: obzor teoreticheskih koncepcij, jempiricheskih issledovanij i metodik diagnostiki. Uchenye zapiski SPbGIPSR. 2020; 1; 33: 50-60. Russian.

13. Hobfoll SE. Stress, culture, and community. N.Y.: London, 1998; 296 p.

14. Vodopjanova N. E. Protivodejstvie sindromu vygoranija v kontekste resursnoj koncepcii cheloveka. Vestnik Sankt-Peterburgskogo universiteta. Serija: Psihologija. 2011; 3: 38-50. Russian.

15. Kobasa SC. Stressful life events, personality, and health — inquiry into hardiness. Journal of Personality and Social Psychology. 2011; 37 (1): 1-11.

16. Maddi S. The Courage and Strategies of Hardiness as Helpful in Crowing Despite Major, Destructive Stresses. American Psychologist. 2008; 63; 6: 563-4.

17. Bartone PT, Valdes JJ, Sandvik A. Psychological Hardiness Predicts Cardiovascular Health. Psychology, Health and Medicine. 2016; 21 (6): 743-9.

18. Nordmo M, Hystad SW, Sanden S, Johnsen BH. The effect of hardiness on symptoms of insomnia during a naval mission. International Maritime Health. 2017; 68 (3): 147-52.

\section{Литература}

1. Твердохлебова Т. И., Ковалёв Е. В., Карпущенко Г. В., Кулак М. А., Думбадзе О. С., Литовко А. Р. и др. Социальноэкономические аспекты COVID-19 на примере Ростовской области. Инфекционные болезни. 2020; 18 (4): 27-32. DOI: 10.20953/1729-9225-2020-4-27-32.

2. Сорокин М. Ю., Касьянов Е. Д., Рукавишников Г. В., Макаревич О. В., Незнанов Н. Г., Лутова Н. Б., и др. Структура тревожных переживаний, ассоциированных с распространением COVID-19: данные онлайн-опроса. Вестник
19. Maddi SR. The Role of Hardiness and Religiosity in Depress and Anger. International Journal of Existential Psychology \& Psychotherapy. 2004; 1; 1: 38-49.

20. Stecishin RI. Zhiznestojkost' kak akmeologicheskij resurs lichnosti vracha. Psihologicheskie problemy smysla zhizni i akme. V sbornike: Materialy XIII simpoziuma; 19 aprelja 2008 g.; M.: PI RAO, 2008; 63-65. Russian.

21. Soboleva AE. Vzaimosvjaz' zhiznestojkosti i otnoshenija k rabote u medicinskih rabotnikov. Ustojchivoe razvitie nauki i obrazovanija. 2018; 8: 46-50. Russian.

22. Fomina NF, Fedoseeva TE. Issledovanie pokazatelej zhiznestojkosti $\checkmark$ aspekte lichnosti professionala. Sovremennye problemy nauki i obrazovanija [internet]. 2016; 6; [cited 2021 August 19]. Dostupno po ssylke: https://science-education.ru/ru/article/view?id=25947. Russian.

23. Abdollahi A, Abu Talib M, Yaacob SN, Ismail Z. Hardiness as a mediator between perceived stress and happiness in nurses. Journal of Psychiatry and Mental Health Nursing. 2014; 21 ; 9: 789-96.

24. Ablett J. Resilience and well-being in palliative care staff: a qualitative study of hospice nurses experience of work. PsychoOncology. 2007; 16; 8: 733-740.

25. Lambert V, Lambert C, Petrini M, Xiao M, Zhang Y. Workplace and social factors associated with physical and mental health in hospital nurses in China. Nursing and Health Sciences. 2007; 9: 120-6.

26. Hobfoll SE. Stress, culture, and community. N.Y.: London, 1998; $296 \mathrm{p}$.

27. Hobfoll SE, Lilly RS. Resource conservation as a strategy for community psychology. Journal of Community Psychology. 1993; 21: 128-48.

28. Vodopjanova NE. Protivodejstvie sindromu vygoranija v kontekste resursnoj koncepcii cheloveka. Vestnik Sankt-Peterburgskogo universiteta. Serija: Psihologija. 2011; 3: 38-50. Russian.

29. Ustav (Konstitucija) Vsemirnoj Organizacii. 2020; [cited 2021 July 13]. Dostupno po ssylke: https://docs.cntd.ru/document/901977493.

30. Noskova OG. Problemy psihologii dejatel'nosti i ee sub"ekta $\checkmark$ tvorchestve E. A. Klimova (k 90-letiju so dnja rozhdenija). Psihologicheskij zhurnal. 2021; 2; 42: 106-14. Russian.

31. Leontev D. A., Rasskazova E. I. Test zhiznestojkosti. M.: Smysl, 2006; 63 s. Russian.

32. Vodopjanova N. E. Stress-menedzhment. M.: Jurait, 2018; 283 s. Russian.

33. Kostjuchenko EV, Romanchuk LN. Svjaz' zhiznestojkosti i optimizma medicinskih rabotnikov. Aktual'nye problemy psihologii razvitija lichnosti. Sbornik nauchnyh statej. Grodno: GrGU im. Janki Kupaly [internet]. 2017; 205-16 [cited 2021 August 19]. Dostupno po ssylke: https://elib.grsu.by/doc/23846. Russian.

34. Jasko BA, Kazarin BV. Model' lichnosti specialista: metodologicheskoe obosnovanie i prakticheskaja vostrebovannost' Organizacionnaja psihologija. 2020; 10; 4: 109-37. [cited 2021 August 19]. Dostupno po ssylke: https://orgpsyjournal.hse.ru/ data/2021/01/03/1344689973/OrgPsy_2020_4 (6)_Yasko-Kazarin (109-137).pdf. Russian.

35. Rasskazova El, Gordeeva TO. Koping-strategii v strukture lichnostnogo potenciala. Lichnostnyj potencial: struktura i diagnostika. M.: Smysl, 2011; 267-99. Russian.

Российского Государственного Медицинского Университета [интернет]. 2020; 3: 77-84.

3. КуфтякЕ. В., Бехтер А. А. Стресс и проактивное совладающее поведение в период пандемии COVID-19: данные онлайнопроса. Медицинская психология в России. 2020; 12; 6 (65) [cited 2021 July 13]. Доступно по ссылке: http://mprj.ru/archiv global/2020_6_65/nomer05.php.

4. Aspinwall LG, Taylor SE. Modeling cognitive adaptation: A longitudinal investigation of the impact of individual differences 
and coping on college adjustment and performance. Journal of Personality and Social Psychology. 1992; 63; 6: 989-1003. DOI: 10.1037//0022-3514.63.6.989.

5. Цзыхань Л., Сяо Ган В. Психологические факторы посттравматического стресса, вызванного пандемией COVID-19. Психологический журнал. 2021; 42; 1: 102-10.

6. Юревич А. В., Ушаков Д. В., Юревич М. А. COVID-19: результаты третьего экспертного опроса. Психологический журнал. 2021; 42; 3: 28-136.

7. Платонова Т. А., Голубкова А. А., Смирнова С. С., Дьяченко Е. В. Актуальные вопросы организации иммунопрофилактики населения. Коммуникативные риски - нерешенные проблемь и новые возможности. Инфекционные болезни. 2020; 18 (3): 112-8. DOI: 10.20953/1729-9225-2020-3-112-118.

8. Франкл В. Человек в поисках смысла. М.: Прогресс, 1990; 368 c.

9. Maddi S. Hardiness: an Operationalization of Existential Courage. Journal of Humanistic Psychology. 2007; 44; 3: 279-98.

10. Maddi S. Hardiness: The courage to grow from stresses. The Journal of Positive Psychology. 2006; 1 (3): 160-8.

11. Одинцова М. А. Психология жизнестойкости. М.: ФЛИНТА, 2015; 296 c.

12. Ярощук И. В. Психология жизнестойкости: обзор теоретических концепций, эмпирических исследований и методикдиагностики. Ученые записки СПбГИПСР. 2020; 1; 33: 50-60.

13. Hobfoll SE. Stress, culture, and community. N.Y.: London, 1998; $296 \mathrm{p}$.

14. Водопьянова Н. Е. Противодействие синдрому выгорания в контексте ресурсной концепции человека. Вестник СанктПетербургского университета. Серия: Психология. 2011; 3: 38-50.

15. Kobasa SC. Stressful life events, personality, and health — inquiry into hardiness. Journal of Personality and Social Psychology. 2011; 37 (1): 1-11.

16. Maddi S. The Courage and Strategies of Hardiness as Helpfu in Crowing Despite Major, Destructive Stresses. American Psychologist. 2008; 63; 6: 563-4.

17. Bartone PT, Valdes JJ, Sandvik A. Psychological Hardiness Predicts Cardiovascular Health. Psychology, Health and Medicine. 2016; 21 (6): 743-9.

18. Nordmo M, Hystad SW, Sanden S, Johnsen BH. The effect of hardiness on symptoms of insomnia during a naval mission. International Maritime Health. 2017; 68 (3): 147-52.

19. Maddi SR. The Role of Hardiness and Religiosity in Depress and Anger. International Journal of Existential Psychology \& Psychotherapy. 2004; 1; 1: 38-49.

20. Стецишин Р. И. Жизнестойкость как акмеологический ресурс личности врача. Психологические проблемы смысла жизни и акме. В сборнике: Материалы XIII симпозиума; 19 апреля 2008 г.; М.: ПИ РАО, 2008; 63-65.

21. Соболева А. Е. Взаимосвязь жизнестойкости и отношения к работе у медицинских работников. Устойчивое развитие науки и образования. 2018; 8: 46-50.

22. Фомина Н. Ф., Федосеева Т. Е. Исследование показателей жизнестойкости в аспекте личности профессионала. Современные проблемы науки и образования [интернет]. 2016; 6; [cited 2021 August 19]. Доступно по ссылке: https:// science-education.ru/ru/article/view?id=25947.

23. Abdollahi A, Abu Talib M, Yaacob SN, Ismail Z. Hardiness as a mediator between perceived stress and happiness in nurses. Journal of Psychiatry and Mental Health Nursing. 2014; 21; 9: 789-96.

24. Ablett J. Resilience and well-being in palliative care staff: a qualitative study of hospice nurses experience of work. PsychoOncology. 2007; 16; 8: 733-740.

25. Lambert V, Lambert C, Petrini M, Xiao M, Zhang Y. Workplace and social factors associated with physical and mental health in hospital nurses in China. Nursing and Health Sciences. 2007; 9: 120-6.

26. Hobfoll SE. Stress, culture, and community. N.Y.: London, 1998; $296 \mathrm{p}$.

27. Hobfoll SE, Lilly RS. Resource conservation as a strategy for community psychology. Journal of Community Psychology. 1993; 21: $128-48$

28. Водопьянова Н. Е. Противодействие синдрому выгорания в контексте ресурсной концепции человека. Вестник СанктПетербургского университета. Серия: Психология. 2011; 3: 38-50.

29. Устав (Конституция) Всемирной Организации. 2020; [cited 2021 July 13]. Доступно по ссылке: https://docs.cntd.ru/ document/901977493.

30. Носкова О. Г. Проблемы психологии деятельности и ее субъекта в творчестве Е. А. Климова (к 90-летию со дня рождения). Психологический журнал. 2021; 2; 42: 106-14.

31. Леонтьев Д. А., Рассказова Е. И. Тест жизнестойкости. М.: Смысл, 2006; 63 с.

32. Водопьянова Н. Е. Стресс-менеджмент. М.: Юрайт, 2018; 283 с.

33. Костюченко Е. В., Романчук Л.Н.Связь жизнестойкости и оптимизма медицинских работников. Актуальные проблемь психологии развития личности. Сборник научных статей. Гродно: ГрГУ им. Янки Купалы [интернет]. 2017; 205-16 [cited 2021 August 19]. Доступно по ссылке: https://elib.grsu.by/ doc/23846

34. Ясько Б. А., Казарин Б. В. Модель личности специалиста: методологическое обоснование и практическая востребованность. Организационная психология. 2020; 10; 4: 109-37. [cited 2021 August 19]. Доступно по ссылке: https://orgpsyjournal.hse.ru/data/2021/01/03/1344689973/ OrgPsy_2020_4 (6)_Yasko-Kazarin (109-137).pdf.

35. Рассказова Е. И., Гордеева Т. О. Копинг-стратегии в структуре личностного потенциала. Личностный потенциал: структура и диагностика. М.: Смысл, 2011; 267-99. 